\title{
ANALISIS KESALAHAN PENGUNAAN HURUF KAPITAL DAN TANDA BACA PADA KARANGAN SEDERHANA SISWA KELAS III SDN II KELAPA DUA KABUPATEN TANGERANG
}

\author{
Dewi Mei Mulyani ${ }^{1}$, Hamdah Siti Hamsanah Fitriani ${ }^{2}$ \\ Universitas Muhammadiyah Tangerang \\ vitrianivit@gmail.com
}

\begin{abstract}
Abstrak
Penelitian ini bertujuan untuk mengetahui kesalahan siswa dalam menggunakan huruf kapital dan tanda baca pada karangan sederhana pada siswa kelas III SDN Kelapa Dua II. Metode yang digunakan dalam penelitian ini adalah metode kualitatif deskriptif, yaitu mengkaji dan mengalisis data secara objektif sesuai dengan data yang ditemukan dilapangan. Hasil penelitian ini ditemukan pada 28 tulisan siswa yang telah dianalisis, terdapat kesalahan penulisan huruf kapital siswa pada karangan sederhana sebanyak 489 kesalahan dari 1874 data atau 26,09\%. Sedangkan kesalahan perletakan tanda baca pada karangan sederhana yang telah ditulis siswa sebanyak 426 kesalahan dari 1874 data atau 22,73\%. Ini menunjukan hampir semua siswa kelas III SDN II Kelapa Dua memahami penggunaan penggunaan huruf kapital dan tanda baca.
\end{abstract}

Kata kunci : huruf kapital, tanda baca, karangana.

\section{A. Pendahuluan}

Pendidikan merupakan suatu kebutuhan penting dalam kehidupan manusia. Pendidikan merupakan kebutuhan bagi manusia untuk menuju kejenjang lebih baik lagi, baik untuk orang lain maupun untuk diri kita sendiri. Pendidikan juga menjadi faktor yang sangat penting bagi kehidupan masyarakat agar berkehidupan berbangsa dan bernegara. Pendidikan juga merupakan faktor yang penting bagi kemajuan untuk negara, karena dengan adanya pendidikan akan melahirkan sumber daya manusia yang berkualitas. Menurut UU No. 20 Tahun 2003 tentang Sistem Pendidikan Nasioanal Sebagai berikut "Pendidikan adalah usaha sadar terencana untuk mewujudkan suasana belajar dan proses pembelajaran agar perserta didik secara aktif mengembangkan potensi dirinya untuk memiliki kekuatan spiritual keagamaan, pengendalian diri, kepribadian kecerdasan, akhlak mulia, serta keterampilan yang diperlukan dirinya, masyarakat, bangsa dan negara”. 
Pembelajaran bahasa merupakan pembelajaran yang penting karena bahasa merupakan modal seseorang dalam berkomunikasi. Seseorang yang pandai berkomunikasi baik melalui tulisan maupun lisan maka ia dapat menyampaikan perasaan, gagasan maupun pesan dengan baik kepada pendengar. Selain itu, ia dapat menarik perhatian pendengar apabila ia memiliki komunikasi yang baik. Di dalam pembelajaran bahasa terdapat empat keterampilan yaitu menyimak, berbicara, membaca dan menulis. keterampilan menulis merupakan keterampilan yang paling sulit dan paling kompleks karena melibatkan ketiga keterampilan yang lain. Menulis yang baik haruslah sesuai dengan kaidah kebahasaan. Sehingga tulisannya mampu menyampaikan pesan dan maksud dari penulis dengan baik. Di dalam kaidah bahas terdapat aturan dalam penggunaan hurf kapital dan tanda baca. Namun, banyak orang yang mengabaikan tata tulis mengenai pengggunaan kapital dan tanda baca.

Berdasarkan pengamatan di kelas III SDN II Kelapa Dua Kabupaten Tangerang, terdapat masalah yang sering dijumpai dalam penggunaan huruf kapital dan tanda baca yaitu salah satunya penempatan huruf kapital yang tidak sesuai dengan kaidah kaidah yang telah ditetapkan. Begitu pula dengan penempatan tanda baca dalam menuliskan karangan sederhana. Banyak siswa yang salah menempatkan tanda baca yang benar dan pemakaian huruf kapital yang benar. Hal tersebut terjadi karena minimnya pengetahuan siswa terhadap kaidah kaidah penulisan huruf kapital dan tanda baca.Maka dari itu menulis juga sesuatu hal yang kurang diminati oleh peserta didik sehingga peserta didik kesulitan dalam menulis dengan ketentuan yang sudah ditetapkan. Menulis juga bukan sekedar menyoretkan tinta dikertas melainkan banyak hal hal yang dapat kita peroleh dari menulis, Seperti saat ini, banyak perserta didik bahkan orang orang yang sudah lulus dalam jenjang pendidikan pun, dalam menuliskan suatu karangan masih banyak yang belum memahami bagaimana menuliskan huruf kapital dengan benar. Masih banyak pula yang masih kurang paham dimana meletakan tanda baca pada suatu karangan sederhana. Masih banyak yang belum paham bagaimana cara menuliskan huruf kapital pada karangan sederhana yang berdasarkan penulisan berdasarkan ketentuan ketetepan EYD. Terkadang bukan hanya kalimat atau karangan sederhana banyak juga yang salah menggunakan huruf kapital pada penulisan suatu judul masih banyak yang keliru dalam menempatkannya. Dan disinilah guru perlu memperhatikan masalah masalah yang terjadi pada perserta didik. 


\section{B. Kajian Pustaka}

Ejaan merupakan kaidah yang harus dipatuhi oleh pemakai bahasa demi keteraturan dan keseragaman bentuk, terutama dalam bahasa tulis. Keteraturan bentuk akan berimplikasi pada ketepatan dan kejelasan makna. Ibarat sedang mengemudi kendaraan, ejaan adalah rambu lalu lintas yang harus dipatuhi oleh setiap pengemudi.Jika para pengemudi mematuhi rambu-rambu yang ada terciptalah lalu lintas yang tertib dan teratur seperti itulah kira kira bentuk hungan antara pemakai bahasa dan ejaan. Pengertian dari huruf kapital itu sendiri adalah huruf yang berukuran dan berbentuk khusus, lebih besar dari huruf biasanya, dan biasanya digunakan sebagai huruf pertama dari kata pertama dalam kalimat, huruf pertama nama diri dan sebagainya. Menurut Kosasih (2012:139-143) dalam menuliskan huruf kapital terdapat banyak kaidah-kaidah atau aturan-aturan yang telah ditetapkan diantaranya sebagai berikut:

1. Huruf kapital atau huruf besar dipakai sebagai huruf pertama kata pada awal kalimat.

2. Huruf kapital dipakai sebagai huruf pertama petikan langsung.

3. Huruf kapital dipakai sebagai huruf pertama dalam ungkapan yang berhubungan dengan nama Tuhan dan kitab suci, termasuk kata ganti untuk Tuhan.

4. Huruf kapital dipakai sebagai huruf pertama nama gelar kehormatan, keturunan, dan keagamaan yang diikuti nama orang.

5. Huruf kapital dipakai sebagai huruf pertama unsur nama jabatan dan pangkat yang diikuti nama orang yang dipakai sebagai pengganti nama orang tertentu, nama instansi, atau nama tempat.

6. Huruf kapital dipakai sebagai huruf pertama unsur-unsur nama orang.

7. Huruf kapital dipakai sebagai huruf pertama nama bangsa, suku bangsa, dan bahasa.

8. Huruf kapital dipakai sebagai huruf pertama nama tahun, bulan, hari, hari raya, dan peristiwa sejarah.

9. Huruf kapital dipakai sebagai huruf pertama nama geografi. 
10. Huruf kapital dipakai sebagai huruf pertama semua unsur negara, lembaga pemerintah dan ketatanegaraan, serta nama dokumen doukmen resmi kecuali kata dan.

11. Huruf kapital dipakai sebagai huruf pertama setiap unsur bentuk ulang sempurna yang terdapat pada nama badan, lembaga pemerintah dan ketatanegaraan, serta dokumen resmi.

12. Huruf kapital dipakai sebagai huruf pertama semua kata (termasuk semua unsur kata ulang sempurna) di dalam nama buku, majalah, surat kabar, dan judul karangan kecuali kata seperti di, ke, dari, dan, yang, dan untuk yang tidak terletak pada posisi awal.

13. Huruf kapital dipakai sebagai huruf pertama unsur singkatan nama gelar, pangkat dan sapaan.

14. Huruf kapital dipakai sebagai huruf pertama kata petunjuk hubungan kekerabatan seperti bapak, ibu, saudara, kakak, adik, dam paman yang dipakai dalam penyapaan dan pengacuan.

15. Huruf kapital dipakai sebagai huruf pertama kata ganti Anda.

Salah satu yang sering dilupakan oleh siswa dalam menuliskan karangan sederhana maupun menulis yaitu penggunaan tanda baca. Padahal penggunaan tanda baca dalam menulis dapat membantu pembaca memahami isi bacaan. Coba saja banyangkan jika teks atau bacaan yang tidak menggunakan tanda baca, mungkin bacaan tersebut kurang dipahami atau bahkan tidak dapat dipahami. Tanda baca juga tidak bisa dipisahkan dari sebuah tulisan. Setiap kali menulis pasti kita menggunakan tanda baca. Tanda baca berfungsi sebagai pembaca untuk memahami bagian dari kalimat yang dituliskan pada suatu bacaan. Menurut Kosasih (2012, 147-148) kaidah penulisan tanda titik sebagai berikut:

1. Tanda titik dipakai pada akhir kalimat yang bukan pernyataan atau seruan.

2. Tanda titik dipakai di belakang angka atau huruf dalam suatu bagan, ikhtisar, atau daftar.

3. Tanda titik dipakai untuk memisahkan angka jam, menit, dan detik yang menunjukan waktu.

4. Penulisan waktu dengan angka dalam sistem 24 jam tidak memerlukan keterangan pagi, siang, sore, malam. 
5. Tanda titik dipisahkan untuk memisahkan angka jam, menit, dan detik yang menunjukkan jangka waktu.

6. Tanda titik dipakai dalam daftar pustaka diantara nama penulis, judul tulisan yang tidak berakhir dengan tanda tanya atau tanda seru, dan tempat terbit.

7. Tanda titik dipakai untuk memisahkan bilangan ribuan atau kelipatan yang menunjukan jumlah.

Menurut E. Zainal Arifin, S. Amran Tasai (2010) Cermat Berbahasa Indonesia, menyatakan bahwa ada kaidah yang mengatur kapan tanda koma digunakan dan kapan tanda koma tidak digunakan:

1. Tanda koma harus digunakan di antara unsur-unsur dalam suatu perincian atau pembilangan.

2. Tanda koma harus digunakan untuk memisahkan kalimat setara yang satu dari kialimat setara berikutnya yang didahului oleh kata tetapi, melainkan, dan sedangkan.

3. Tanda koma harus digunakan untuk memisahkan anak kalimat dari induk kalimat apabila anak kalimat tersebut mendahului induk kalimatnya. Biasanya, anak kalimat didahului oleh kata penghubung bahwa, karena, agar, sehingga, walaupun, apabila, jika, meskipun, dan sebagainya.

Menulis bukan hanya melahirkan pemikiran namun elahirkan ide, ilmu pengetahuan dan pengalaman hidup seseorang dalam bahasa tulis (Saddhono dan Slamet, 2014:151). Menulis adalah suatu kegiatan untuk menciptakan suatu catatat atau informasi pada sesuatu media dengan menggunakan tulisan. Menulis juga merupakan salah satu kemampuan berbahasa, menulis juga hal yang sangat penting bagi mereka yang tidak bias berbicara dan mendengar.

Tujuan menulis, di bawah ini hanya dikemukakan beberapa tujuan, antara lain:

1) Tulisan yang bertujuan untuk memberitahukan atau mengajar biasa disebut dengan wacana informatif (informative discourse).

2) Tulisan yang bertujuan untuk meyakinkan atau mendesak disebut jugawacana persuasif (persuasive discourse) 
3)Tulisan yang bertujuan untuk menghibur atau menyenangkan yangmengandung tujuan estetik disebut tulisan literer (wacana kesastraan atauliterary discourse)

4) Tulisan yang bertujuan untuk mengekspresikan perasaan dan emosi yangkuat berapi-api disebut wacana ekspresif (expessive discourse)

\section{Metode Penelitian}

Penelitian yang digunakan oleh peneliti ini menggunakan penelitian kualitatif Deskriptif. Peneliti berupaya untuk menganalisis karanagan sederhana siswa terhadap kesalaahan dalam menggunakan hururf kapital dan tanda baca. Oleh karena itu, metode deskriptif kualitatif ini dipandang sesuai untuk mengkaji dan menganalisis data secara objektif sesuia dengan data yang ditemukan dilapangan. Sumber data dalam penelitian ini adalah guru dan siswa sebanyak 28 siswa dengan menggunakan metode observasi serta siswa diberi tes berupa esai. Data dalam penelitian ini yaitu hasil tulisan siswa dalam bentuk karangan sederhana sebanyak 28 siswa-siswi yang selanjutnya data tersebut akan diolah dan dianalisis oleh peneliti sehingga adanya kesalahan dalam penulisan karangan sederhana siswa.

Teknik pengumpulan data dalam penelitian ini, data dikumpulkan melalui beberapa teknik diantaranya yaitu wawancara, observasi, tes, dan dokumentasi. Wawancara ini dilakukan kepada wali kelas III dan digunakan untuk menggali informasi tentang sistem pembelajaran yang dilakukan didalam kelas, metode apa saja yang digunakan didalam pembelajaran didalam kelas, mengetahui kondisi kelas saat proses pembelajaran didalam kelas, dan untuk mengetahui apakah banyak siswa yang masih salah dalam penggunaan huruf kapital dan tanda baca. Penelitian ini, menggunakan metode observasi dilakukan dengan cara yaitu peneliti mengamati tulisan siswa di buku tulis yang dimiliki siswa dalam pelaksanaan proses belajar mengajar yang dilakukan didalam kelas. Penelitian juga menggunakan teknik tes berupa esai dalam mengumpulkan data. Tes yang dimaksudkan disini ialah peneliti mengumpulkan hasil tulisan siswa dalam bentuk karangan sederhana yang berupa esai dari28 siswa-siswi yang selanjutnya data tersebut akan diolah dan dianalisis oleh peneliti sehingga peneliti dapat mengetahui adanya kesalahan dalam penggunaan huruf kapital dan tanda baca dalam penulisan karangan sederhana siswa. Dokumentasi yaitu mencari sumber-sumber 
data yang diperlukan yang berada dilapangan dan berkaitan dengan penelitian yang ingin diteliti oleh peneliti. Dokumetasi diantaranya itu berupa foto-foto.

Teknik analisis data yaitu dengan teknik reduksi data dan analisis data. Teknik analisis data yang digunakan dalam penelitian ini yaitu dengan reduksi data yaitu dengan memilih data yang sesuai dengan kesalahan penggunaan kapital dan tanda baca. Setelah itu dilakukan penyajian data yaitu dengan menganalisis yang bertujuan untuk mendeskripsikan dan menganalisis kesalahan yang dibuat oleh siswa kelas III SDN II Kelapa Dua Kabupaten Tangerang.

\section{Pembahasan}

Pengumpulan data berlangsung selama empat hari, terhitung dari hari SelasaJumat. Pada hari selasa, peneliti menyerahkan surat izin penelitian kesekolah untuk diizinkan melakukan penelitian serta menjelaskan maksud dan tujuan melakukan penelitian. Pada hari selasa, peneliti melakukan wawancara kepada guru untuk menggali informasi tentang pembelajaran siswa menulis karangan sederhana dikelas, metode yang digunakan pada saat pembelajaran menulis, kondisi kelas saat pembelajaran siswa kelas III SD Negeri Kelapa II Dua Kabupaten Tangerang.

Wawancara ini juga digunakan untuk mengetahui hal-hal yang berhubungan dengan pengetahuan siswa dalam membuat karangan sederhana khusunya dengan penggunaan huruf kapital dan tanda baca yang baik dan benar.Pada hari Rabu, peneliti datang ke kelas III untuk memberikan pemahaman membuat karangan sederhana.Pada hari Kamis, peneliti mengumpulkan data yang berupa dokumentasi hasil tulisan siswa dalam bentuk karangan sederhana, dengan siswa keseluruhan siswa 28 siswa.Penelitian yang dilakukan pada hari Jum'at peneliti menyampaikan kepada kepala sekolah bahwa penelitian telah selesai dilaksanakan namun jika ada data-data yang masih kurang maka peneliti diperbolehkan untuk datang lagi kesekolah.

Kemampuan menulis dengan menerapakan kaidah penulisan huruf kapital dan tanda baca secara tepat dari hasil tulisan siswa dalam membuat karangan sederhana ternyata sangat bervariasi.Untuk tanda baca peneliti menbatasi penelitian pada tanda baca, peneliti meneliti hanya meneliti tentang tanda baca berupa tanda titik dan tanda koma, sebagaimana yang sudah dijelaskan pada BAB II.Berikut ini peneliti akan 
menguraikan tentang kesalahan siswa dalam penulisan huruf kapital dan tanda baca pada karangan sederhana.

Data 1 : aku hari Minggu aku mengajak ayah Ibuku pergi kebanten.

Kalimat di atas kurang tepat, seharusnya huruf "a" pada kata "aku" menggunakan huruf kapital, begitu pula huruf "I" pada kata "Ibu" seharusnya menggunakan huruf kecil karena tidak terdapat pada awalan kalimat, yaitu didalam EYD disebutkan "Huruf kapital dipakai sebagai huruf pertama semua kata (termasuk semua unsur kata ulang sempurna) di dalam nama buku, majalah, surat kabar, dan judul karangan kecuali kata seperti di, ke, dari, dan, yang, untuk, yang tidak terletak pada posisi awal". Huruf "b" pada kata "kebanten" seharunya kata "ke" dipisah dengan kata "banten" dan huruf "b" pada kata "banten" seharusnya menggunakan huruf kapital karena huruf kaital dipakai sebagai huruf pertama nama geografi.

Perbaikan : Aku hari Minggu aku mengajak ayah ibuku pergi ke Banten.

Data 2 : hari minggu saya berenang, saya berangkat bersama ayah, ibu, dan adik.

Kalimat tersebut di atas kurang tepat, seharusnya huruf "h" pada kata "hari" menggunakan huruf kapital karena terdapat pada awalan kalimat, yaitu didalam EYD disebutkan "Huruf kapital dipakai sebagai huruf pertama semua kata (termasuk semua unsur kata ulang sempurna) di dalam nama buku, majalah, surat kabar, dan judul karangan kecuali kata seperti di, ke, dari, dan, yang, untuk, yang tidak terletak pada posisi awal". Huruf "m" pada kata "minggu" seharusnya menggunakan huruf kapital, karena huruf kapital dipakai sebagai huruf pertama nama tahun, bulan, hari, hari raya, dan peritiwa sejarah.

Perbaikan : Hari Minggu saya berenang, saya berangkat bersama ayah, ibu, dan adik.

Data 3 : Pada suatu hari Aku dan ayahku berlibur ibuku dan aku berlibur ke jakarta Timur.

Kalimat tersebut di atas kurang tepat, seharusnya huruf "A" pada kata "Aku" menggunakan huruf kecil, karena bukan awalan kalimat dan seharusnya menggunakan 
huruf kecil. Huruf “j” pada kata "jakarta” seharusnya menggunakan huruf kapital karena huruf kapital dipakai sebagai huruf pertama nama suatu tempat.

Perbaikan: Pada suatu hari aku dan ayahku berlibur ibuku dan aku berlibur ke Jakarta Timur.

Data 4 : aku pergi kepantai bersama ibuku dan kakakku.

Analisis : kalimat tersebut di atas salah dalam penggunaan huruf kapital, seharusnya huruf "a" pada kata "aku" menggunakan huruf kapital karena terdapat pada awalan kalimat selain itu kata "kepantai" seharusnya dipisah karena menunjukkan tempat.

Perbaikan: Aku pergi ke pantai bersama ibuku dan kakakku.

Data 5 : pada hari minggu saya ke mall bersama adiku aku senang sekali dan aku bermain perang tembak adikku bermain pemancingan dan ibuku makan mcdonals.

Kalimat tersebut di atas kurang tepat, seharusnya huruf "p" pada kata "pada" menggunakan huruf kapital karena terdapat pada awalan kalimat. Huruf "m" pada kata "minggu" seharusnya menggunakan huruf kapital, karena huruf kapital dipakai sebagai huruf pertama nama tahun, bulan, hari, hari raya, dan peritiwa sejarah. Sedangkan huruf "m" pada kata "mcdonals" menggunakan huruf kapital karena huruf kapital dipakai sebagai huruf singkatan nama. Pada kata "adiku" dan kata "aku”, kata "sekali" dan "dan", kata "pemancingan" dan "dan" seharusnya menggunakan tanda koma karena menunjukkan adanya kalimat majemuk. Namun apabila tidak menggunakan koma maka terjadi keracuan kalimat.

Perbaikan : Pada hari Minggu saya ke mall bersama adikku, aku senang sekali, dan bermain perang tembak adikku bermain pemancingan, dan ibuku makan Mc Donald.

Data 6 : aku pergi ke pantai bersama ibuku adik dan aku bermain di pinggir pantai dan aku bermain basah basahan.

Kalimat tersebut di atas kurang tepat, seharusnya huruf "a" pada kata "aku" menggunakan huruf kapital karena terdapat pada awalan kalimat, yaitu didalam EYD 
disebutkan "Huruf kapital dipakai sebagai huruf pertama semua kata. Pada kata "ibuku”, "adik", dan "aku” seharusnya menggunakan tanda baca koma sebagai pemisah rincian, dan pada kata "pantai" dan "aku” seharusnya menggunakan tanda koma untuk membedakan antara anak dan induk kalimat.

Perbaikan : Aku pergi ke pantai bersama ibuku, adik, dan aku bermain di pigir pantai, dan aku bermain basah basahan.

Data 7 : aku berlibur ke pantai dan aku senang sekali aku bersama ayah ibu adik kakak.

Kalimat di atas tersebut kurang tepat, seharusnya huruf "a" pada kata "aku" menggunakan huruf kapital karena terdapat pada awalan kalimat. Pada penulisan "ayah", "ibu”, "adik", "kakak" seharusnya menggunakan tanda koma karena tanda koma harus digunakan di antara unsur-unsur dalam suatu perincian atau pembilangan.

Perbaikan: Aku berlibur ke pantai dan aku senang sekali aku bersama ayah, ibu, adik dan kakak.

Data 7: Pas itu aku dan keluargaku pergi keancol aku bersama ayah, bunda, dek putra dan dll.

Kalimat tersebut di atas kurang tepat, huruf "a" pada kata "Ancol" semenggunakan huruf kapital karena huruf kaital dipakai sebagai huruf pertama nama geografi.

Perbaikan: Pas itu aku dan kelauragaku pergi ke Ancol bersama ayah, bunda, dek putra dll.

Data 8 : Pada hari minggu aku dan keluargaku pergi ke pantai jam 07:00aku dan keluargaku menaiki mobil pribadi.

Kalimat tersebut di atas kurang tepat, huruf "m" pada kata "minggu" seharusnya menggunakan huruf kapital, karena huruf kapital dipakai sebagai huruf pertama nama tahun, bulan, hari, hari raya, dan peritiwa sejarah. Kemudian penempatan tanda " : " pada penulisan “07:00” seharusnya menggunakan tanda titik karena tanda titik dipakai untuk memisahkan angka jam, menit, dan detik yang menunjukan waktu. 
Perbaikan: Pada hari Minggu aku dan keluargaku pergi ke pantai jam $07.00 \mathrm{aku}$ dan keluargaku menaiki mobil pribadi.

\section{Hasil Analisis dan Interprestasi Data}

\begin{tabular}{|l|c|c|c|c|}
\hline No & Aspek Yang Teliti & $\begin{array}{c}\text { Jumlah } \\
\text { Kesalahan }\end{array}$ & $\begin{array}{c}\text { Jumlah kata } \\
\text { yang digunakan }\end{array}$ & persentase \\
\hline 1. & Penggunaan huruf kapital & 489 & 1874 & $26,09 \%$ \\
\hline 2. & Penggunaan tanda baca & 426 & 1874 & $22,73 \%$ \\
\hline
\end{tabular}

Hasil analisis data data dari 28 karangan siswa, ditemukan kesalahan pada aspek:

1. Penggunaan huruf kapital pada karangan sederhana, sebanyak 26.09\%. Ini menunjukan semua siswa kelas III hampirmemahami penggunaan huruf kapital.

2. Penggunaan tanda baca pada karangan sederhana, sebanyak 22,73\%. Ini menunjukan semua siswa kelas III memahami penggunaan tanda baca.

\section{E. Simpulan}

Berdasarkan kajian teoritis dan hasil penelitian yang telah dilakukan mengenai “ Analisis Kesalahan Penggunaan Huruf Kapital dan Tanda Baca Pada Karangan Sederhana Siswa Kelas III SDN II Kelapa DUA Kabupaten Tangerang” maka peneliti dapat menyimpulkan beberapa kesimpulan dan saran. Deskripsi data interprestasi data, penulis dapat mengemukakan kesimpualan yaitu:

1. Berdasarkan 28 tulisan siswa yang telah dianalisis, terhadap penulisan huruf kapital siswa pada karangan sederhana, sebanyak 26,09\% menunjukan bahwa semua siswa kelas III hampir memahami penggunaan huruf kapital.

2. Sedangkan perletakan tanda baca pada karangan sederhana yang telah ditulis siswa, sebanyak 22,73\%. Ini menunjukan semua siswa kelas III hampir memahami penggunaan tanda.

\section{F. Daftar Pustaka}


Lingua Rima: Jurnal Pendidikan Program Studi Bahasa dan Sastra Indonesia Vol. 7 No. 1 Januari 2018

Arifin, E. Zaenal, dan S. Amran Tasai. (2010). Cermat Berbahasa Indonesia untuk Perguruan Tinggi. Bandung: AkademiPressindo.

Kosasih. 2012. Dasar-Dasar Keterampilan Menulis. Bandung: Yrama Widya

Saddhono, Kundharu. 2014. Pembelajaran Keterampilan Berbahasa Indonesia. Yogyakarta:Graha Ilmu 